Aim of the study: The CD30L ligand is a membrane-associated glycoprotein expressed by activated CD4+Th cells, macrophages, dendritic cells, and B lymphocytes. It binds to the CD30 receptor carried on activated and helper Th cells, inducing the immune response and apoptosis. The aim of this retrospective study was to determine the level of SCD30L in the serum of patients at diagnosis of ovarian cancer and at relapse and to assess the potential association of this ligand with selected clinico-pathologic factors. Material and methods: We studied 69 patients with ovarian cancer allocated to two groups: A - ovarian cancer at diagnosis, B - relapse of ovarian cancer and active growth of the tumor.

Results: We found high levels of SCD30L in ovarian cancer patients. Levels at relapse $(21.48 \mathrm{ng} / \mathrm{ml})$ were significantly higher than at diagnosis $(11.81 \mathrm{ng} / \mathrm{ml})$. Poor response to first-line chemotherapy was accompanied by higher levels of SCD30L and by several other findings: resistance to platinum analogs was common, neoadjuvant chemotherapy was needed, relapse and death during two-year follow-up were frequent. Conclusions: Our present study might initially suggest that elevated concentration of SCD30L can be an important finding prognosticating a poor prognosis and is associated with platinum resistant and refractory cases of ovarian cancer. However, studies are needed on larger groups of patients.

Key words: ovarian cancer, apoptosis, CD30L, prognostic factor.

\section{Evaluation of serum levels of SCD30L ligand in patients with ovarian cancer in terms of selected clinico-pathological factors}

\author{
Anita Chudecka-Głaz, Izabella Rzepka-Górska
}

Department of Gynecological Surgery and Gynecological Oncology of Adults and Adolescents, Pomeranian Medical University, Szczecin, Poland

\section{Introduction}

Ovarian cancer is associated with the worst prognosis among female malignancies. Long-term outcomes of therapy are discouraging: ovarian cancer is often diagnosed at an advanced clinical stage and, moreover, the percentage of relapse after first-line chemotherapy is relatively high. The response to treatment in ovarian cancer and other malignant tumors depends to some extent on the interplay between factors engaged in apoptosis [1]. Under physiological conditions, apoptosis contributes to homeostasis by eliminating aging and neoplastic cells as a counterbalance to cell proliferation [1]. Inhibitors and stimulators of apoptosis were found to be dysfunctional in neoplastic cells [2], resulting in impairment of apoptosis, progression of the tumor, and resistance to therapy [2].

The search continues for novel markers of apoptosis which could help us understand the complex processes in carcinogenesis and develop maximally effective and perhaps more individualized therapies [3]. The CD30 ligand (CD30L) is a member of the tumor necrosis factor (TNF) superfamily. This type II membrane-associated glycoprotein with a molecular weight of $40 \mathrm{kDa}$ binds to CD30 as a homotrimer, effectively eliciting cell death. CD30 was first described as a marker of Reed-Sternberg cells in Hodgkin's lymphoma, which are notable for its high expression. CD30, like other members of the TNF superfamily, participates in cell proliferation, differentiation, and death. CD30L is membranebound but is also present in soluble form in serum (SCD30L) [4]. It has been suggested that interactions of CD30 with its ligand CD30L necessary for normal apoptosis are inhibited in ovarian cancer cells because of shedding of CD3OL from the cell surface [5].

There are few reports on the patterns of SCD30L in epithelial tumors and a single report on $\mathrm{SCD} 30 \mathrm{~L}$ in ovarian cancer [3-5]. We therefore decided to conduct a preliminary test study of SCD3OL serum levels in ovarian cancer patients with regard to some clinico-pathologic factors.

\section{Material and methods}

Due to the analytical method used by us, which requires batch testing, we performed a retrospective study using sera collected from patients treated at our Department of Gynecologic Surgery and Oncology. We retrieved the whole medical history, results of histopathology, and CT scans from the database and qualified patients and their sera for the present study. All patients were regularly seen at the Clinic of Gynecologic Oncology, and had complete medical records (Table 1 ).

The patients were allocated to two groups: A - with newly diagnosed ovarian cancer prior to therapy (surgery, chemotherapy); B - with relapse or residual disease after surgery and chemotherapy. Blood $(10 \mathrm{ml})$ was collected one day prior to surgery, neoadjuvant chemotherapy or before second line 
chemotherapy in patients with relapse as part of the routine procedure. Serum was obtained by centrifugation and was immediately stored.

Concentrations of SCD3OL in groups A and B were compared. We studied correlations in group A of pre-operative levels of SCD3OL with some clinico-pathologic factors such as FIGO stage, grade, sensitivity to platinum analogs, disease-free survival (DFS), and two-year survival. Disease-free survival represented the time between the end of first-line chemotherapy and relapse. The National Cancer Institute of the US allows the following parameters, among others, to assess the impact of various factors and drugs on the cancer course: DFS, PFS (progression-free survival), TTP (time to progression), OS (overall survival). Disease-free survival is sometimes replaced by DFI (disease-free interval) by researchers of the ESGO group. Additionally, we looked for a relationship between starting level of sCD3OL and administration of neoadjuvant chemotherapy in patients in whom it was not possible to perform optimal or suboptimal cytoreduction.

Sensitivity to platinum was noted when DFS was at least 6 months from the end of first-line chemotherapy. Patients whose DFS was shorter than six months were termed resistant, whereas patients who did not respond to therapy were termed refractory.

Response to treatment was evaluated based on RECIST criteria. After the last course of chemotherapy, each patient had a CT scan performed and CA 125. Recurrence was diagnosed if there was a measurable change in the CT or an unmeasurable change with a corresponding increase in CA 125. In doubtful single cases PET-CT was performed additionally.

A specific and sensitive enzyme-linked immunoassay from Bender MedSystems (Vienna, Austria) was used for the quantitation of SCD3OL in serum. The limit of detection of human SCD30L defined as the concentration resulting in an absorbance significantly higher than that of the dilution medium was determined to be $0.5 \mathrm{ng} / \mathrm{ml}$. As suggested in the product insert, there was no upper normal limit because SCD30L is not detectable in healthy blood donors.

Statistical analysis was done using STATISTICA 9.1 PL software. Means were compared with the non-parametric Mann-Whitney U test and the Kruskal-Wallis test. Qualitative variables were not analyzed because $S C D 30 \mathrm{~L}$ is not present in healthy human sera and normal limits have not been defined. The level of significance was taken as $p<0.05$.

\section{Results}

Group A consisted of 50 patients with mean age of 55.6 years (32-79), 20 of whom were premenopausal (mean age
Table 1. Characteristics of patients (group A)

\begin{tabular}{|c|c|}
\hline Parameter & $\begin{array}{c}n=50 \text { (total) } \\
\text { Mean age }=55.6 \mathrm{yrs} \\
{[32-79]}\end{array}$ \\
\hline premenopausal Mean age 42.2 years [32-50] & 20 \\
\hline postmenopausal Mean age 64.43 years [50-79] & 30 \\
\hline FIGO I & 10 \\
\hline FIGO II & 7 \\
\hline FIGO III & 33 \\
\hline FIGO IV & 1 \\
\hline Grade 1 & 7 \\
\hline Grade 2 & 17 \\
\hline Grade 3 & 26 \\
\hline serous & 37 \\
\hline mucinous & 4 \\
\hline endometrioid & 2 \\
\hline clear cell & 5 \\
\hline undifferentiated & 2 \\
\hline
\end{tabular}

42.2 years; $32-50$ ) and 30 postmenopausal (mean age 64.43 years; 50-79). Patients with relapse of ovarian cancer were allocated to group B. Relapse was ascertained with diagnostic imaging or histopathology. The mean age in this group was 56 years (43-75). Higher levels of SCD3OL were found in patients with relapse of ovarian cancer (mean $21.48 \mathrm{ng} / \mathrm{ml}$ ) than in patients at diagnosis of the tumor (mean $11.81 \mathrm{ng} / \mathrm{ml}$, $p<0.05$ ). When serous tumors were compared, differences between means were evident but not statistically significant (group A: 12.93 ng/ml, group B: 35.24 ng/ml; Table 2). Mean concentrations of sCD3OL were higher in serous $(12.42 \mathrm{ng} / \mathrm{ml})$ and clear cell tumors $(12.02 \mathrm{ng} / \mathrm{ml})$ than in mucinous tumors $(6.74 \mathrm{ng} / \mathrm{ml})$. We also found higher concentrations of SCD30L in patients with advanced stage and poorly differentiated ovarian cancer. We attribute the lack of statistical significance for these differences to the small size of our groups. The mean sCD3OL level in patients of group A at FIGO clinical stage III was $11.09 \mathrm{ng} / \mathrm{ml}$, in contrast to $7.54 \mathrm{ng} / \mathrm{ml}$ for FIGO I (Table 3). As regards differentiation, we found a mean of $12.4 \mathrm{ng} / \mathrm{ml}$ for grade $3,13.07 \mathrm{ng} / \mathrm{ml}$ for grade 2 , and $7.55 \mathrm{ng} / \mathrm{ml}$ for grade 1 (Table 4).

Patients with newly diagnosed ovarian cancer (group A) were further analyzed with respect to some clinico-pathologic

Table 2. Comparison of $\mathrm{SCD} 30 \mathrm{~L}$ concentrations in group $\mathrm{A}$ and $\mathrm{B}$

\begin{tabular}{|c|c|c|c|c|c|c|}
\hline \multirow[t]{2}{*}{ sCD30L $[\mathrm{ng} / \mathrm{ml}]$} & $\begin{array}{c}\text { Group A } \\
n=50\end{array}$ & $\begin{array}{c}\text { Group B } \\
n=19\end{array}$ & $p$ & $\begin{array}{c}\text { Group A } \\
n=37\end{array}$ & $\begin{array}{c}\text { Group B } \\
n=6\end{array}$ & $p$ \\
\hline & \multicolumn{3}{|c|}{ whole group } & \multicolumn{3}{|c|}{ serous type only } \\
\hline mean & 11.81 & 21.48 & $<0.05$ & 12.93 & 35.24 & 0.362 \\
\hline (range) & $(4.62-82.07)$ & $(5.63-155.87)$ & & $(4.72-82.07)$ & $(5.63-155.87)$ & \\
\hline median & 8.12 & 9.66 & & 8.82 & 11.86 & \\
\hline$(95 \% \mathrm{Cl})$ & $(8.28-15.36)$ & $(5.04-37.91)$ & & $(8.25-17.61)$ & (26.99-97.46) & \\
\hline
\end{tabular}


Table 3. Comparison of sCD30L concentrations in group A depending on clinical stage (FIGO)

\begin{tabular}{|c|c|c|c|c|c|c|c|c|c|}
\hline Group A & FIGO I & FIGO II & $p$ & FIGO I & FIGO III & $p$ & FIGO II & FIGO III & $p$ \\
\hline \multicolumn{10}{|l|}{$\mathrm{sCD} 30 \mathrm{~L}[\mathrm{ng} / \mathrm{ml}]$} \\
\hline whole group & $n=10$ & $n=6$ & 0.328 & $n=10$ & $n=33$ & 0.2272 & $n=6$ & $n=33$ & 0.9070 \\
\hline mean & 7.54 & 11.52 & & 7.54 & 11.09 & & 11.52 & 11.09 & \\
\hline (range) & $(4.62-11.43)$ & $(6.53-33.22)$ & & $(4.62-11.43)$ & $(4.78-37.7)$ & & $(6.53-33.22)$ & $(4.78-37.7)$ & \\
\hline median & 7.49 & 7.03 & & 7.49 & 8.25 & & 7.03 & 8.25 & \\
\hline$(95 \% \mathrm{Cl})$ & $(5.65-9.44)$ & $(2.49-20.56)$ & & $(5.65-9.44)$ & $(8.18-13.99)$ & & $(2.49-20.56)$ & $(8.18-13.99)$ & \\
\hline \multicolumn{10}{|l|}{ sCD30L $[\mathrm{ng} / \mathrm{ml}]$} \\
\hline serous type only & $n=7$ & $\frac{N}{N}$ & & $n=7$ & $n=26$ & $p=0.2709$ & $\frac{N}{n}$ & $n=26$ & \\
\hline mean & 7.66 & 金 & & 7.66 & 12.18 & & 高 & 12.18 & \\
\hline (range) & $(4.72-11.42)$ & $\stackrel{\overline{\bar{\sigma}}}{\overline{\bar{\sigma}}}$ & & $(4.72-11.42)$ & $(4.78-37.7)$ & & $\stackrel{\frac{1}{50}}{=}$ & $(4.78-37.7)$ & \\
\hline median & 8.26 & $\frac{\sigma}{\tilde{n}}$ & & 8.26 & 8.93 & & $\stackrel{\sigma}{\varepsilon}$ & 8.93 & \\
\hline$(95 \% \mathrm{Cl})$ & (5.13-10.18) & & & (5.13-10.18) & $(8.57-15.78)$ & & & $(8.57-15.78)$ & \\
\hline
\end{tabular}

Table 4. Comparison of SCD30L concentrations in group A depending on tumor grade

\begin{tabular}{|c|c|c|c|c|c|c|c|c|c|}
\hline Group A & Grade 1 & Grade 2 & $p$ & Grade 1 & Grade 3 & $p$ & Grade 2 & Grade 3 & $p$ \\
\hline \multicolumn{10}{|l|}{$\mathrm{sCD} 30 \mathrm{~L}[\mathrm{ng} / \mathrm{ml}]$} \\
\hline whole group & $n=7$ & $n=17$ & 0.5048 & $n=7$ & $n=26$ & 0.2175 & $n=17$ & $n=26$ & 0.4266 \\
\hline mean & 7.55 & 13.07 & & 7.55 & 12.4 & & 13.07 & 12.4 & \\
\hline (range) & $(4.72-11.43)$ & $(4.62-82.07)$ & & $(4.72-11.43)$ & $(5.24-37.7)$ & & $(4.62-82.07)$ & $(5.24-37.7)$ & \\
\hline median & 7.13 & 8.49 & & 7.13 & 8.25 & & 8.49 & 8.25 & \\
\hline$(95 \% \mathrm{Cl})$ & $(5.3-9.8)$ & $(3.66-22.48)$ & & $(5.3-9.8)$ & (8.19-13.99) & & $(3.66-22.48)$ & $(8.19-13.99)$ & \\
\hline \multicolumn{10}{|l|}{ sCD30L $[\mathrm{ng} / \mathrm{ml}]$} \\
\hline serous type only & $n=6$ & $n=10$ & 0.2780 & $n=6$ & $n=21$ & 0.3507 & $n=10$ & $n=21$ & 0.7998 \\
\hline mean & 7.72 & 17.27 & & 7.72 & 12.35 & & 17.27 & 12.35 & \\
\hline (range) & $(4.71-11.43)$ & $(5.24-37.7)$ & & $(4.71-11.43)$ & $(5.24-37.7)$ & & $(5.24-37.7)$ & $(5.24-37.7)$ & \\
\hline median & 7.7 & 9.23 & & 7.7 & 8.82 & & 9.23 & 8.82 & \\
\hline$(95 \% \mathrm{Cl})$ & $(4.97-10.47)$ & $(0.57-33.97)$ & & $(4.97-10.47)$ & $(8.03-16.67)$ & & $(0.57-33.97)$ & $(8.03-16.67)$ & \\
\hline
\end{tabular}

factors. We found that patients resistant to first-line chemotherapy based on platinum analogs and paclitaxel had significantly higher levels of sCD3OL $(16.14 \mathrm{ng} / \mathrm{ml})$ compared to patients responding to therapy $(9.33 \mathrm{ng} / \mathrm{ml})$. The difference remained, although statistical significance was lost due to small size of the subgroups, when serous tumors were analyzed (resistant and refractory: $16.6 \mathrm{ng} / \mathrm{ml}$, sensitive: $9.9 \mathrm{ng} / \mathrm{ml}$ ). Patients with complete remission had lower SCD30L levels $(9.78 \mathrm{ng} / \mathrm{ml})$ than those in whom disease-free survival was not observed (17.11 $\mathrm{ng} / \mathrm{ml}, p=0.0127)$. In group A, statistical significance was limited to serous tumors: patients with DFS had lower sCD3OL levels $(10.4 \mathrm{ng} / \mathrm{ml})$ than patients without DFS $(18.11 \mathrm{ng} / \mathrm{ml}$, $p=0.0297)$. Patients requiring neoadjuvant chemotherapy due to progression of the tumor precluding radical surgery had significantly higher concentrations of SCD30L in serum (15.17 $\mathrm{ng} / \mathrm{ml}$ ) than patients who underwent radical surgery and adjuvant chemotherapy $(8.64 \mathrm{ng} / \mathrm{ml}, p=0.115)$. A difference concerning radical surgery and neoadjuvant chemotherapy was also noted for serous tumors $(16.11 \mathrm{ng} / \mathrm{ml}$ for neoadjuvant chemotherapy only and $7.7 \mathrm{ng} / \mathrm{ml}$ for adjuvant chemotherapy after radical surgery, $p=0.0297$ ).

Patients who survived two years had lower levels of sCD30L $(10.33 \mathrm{ng} / \mathrm{ml})$ than patients who died before the end of two-year follow-up $(18.48 \mathrm{ng} / \mathrm{ml})$, but this difference was not statistically significant. Our findings concerning clinicopathologic factors are presented in Table 5.

\section{Discussion}

Reports on the patterns of membrane-bound CD30 ligand and its soluble form in serum (SCD3OL) in patients with ovarian cancer are sparse and most of them deal with the biological functions of CD30 [6], its associations with pathologies of the lymphatic [7] and gastrointestinal [8] systems, and its role in some disorders during pregnancy [9]. Elevated levels of SCD30L in serum have been observed in viral infections, as well as in autoimmune and atopic diseases. The ligand is currently recognized as a marker of the immune response realized chiefly by Th2 cells $[10,11]$.

$\mathrm{CD} 30 \mathrm{~L}$ is a type II membrane-associated glycoprotein with a molecular weight of $40 \mathrm{kDa}$, expressed mainly by activated CD4+Th cells, but also by macrophages, dendritic cells, B lymphocytes and exceptionally by helper CD4+CD3 CD11C cells $[10,12,14]$. Expression of the CD30 receptor has been shown on activated and helper Th cells [15]. CD30 is capable of activating TNF receptor-associated factor 2 (TRAF2) [16] and there is evidence that the binding of CD3OL to CD30 induces a signal which elicits the response of Th1 and Th2 cells. The same mechanism has been imputed in pathologies related to these cells and observations have been published that cytokines released by Th1 and Th2 cells participate in the immune response seen in patients with epithelial ovarian tumors. Expression of IL-12p40/IL- 6 by these cells is of prog- 
Table 5. Comparison of $\mathrm{SCD} 30 \mathrm{~L}$ concentrations in group A depending on prognostic factors

\begin{tabular}{|c|c|c|c|c|c|}
\hline & & $\begin{array}{l}\mathrm{sCD} 30 \mathrm{~L} \text { (all) } \\
{[\mathrm{ng} / \mathrm{ml}]}\end{array}$ & $p$ & $\begin{array}{l}\text { sCD30L (serous) } \\
{[\mathrm{ng} / \mathrm{ml}]}\end{array}$ & $p$ \\
\hline Platinum sensitive & $\begin{array}{l}\text { mean } \\
\text { median } \\
\text { range }\end{array}$ & $\begin{array}{c}9.33 \\
7.58 \\
(6.47-37.7)\end{array}$ & 0.056 & $\begin{array}{c}9.9 \\
8.26 \\
(4.72-37.7)\end{array}$ & 0.1322 \\
\hline $\begin{array}{l}\text { Platinum } \\
\text { resistant/ } \\
\text { refractory }\end{array}$ & $\begin{array}{l}\text { mean } \\
\text { median } \\
\text { range }\end{array}$ & $\begin{array}{c}16.14 \\
8.82 \\
(5.89-82.07)\end{array}$ & & $\begin{array}{c}16.6 \\
9.16 \\
(5.89-82.07)\end{array}$ & \\
\hline $\begin{array}{l}\text { Neoadjuvant } \\
\text { therapy }\end{array}$ & $\begin{array}{l}\text { mean } \\
\text { median } \\
\text { range }\end{array}$ & $\begin{array}{c}15.17 \\
8.93 \\
(5.89-82.07)\end{array}$ & 0.0115 & $\begin{array}{c}16.11 \\
9.16 \\
(5.89-82.07)\end{array}$ & 0.0307 \\
\hline Adjuvant therapy & $\begin{array}{l}\text { mean } \\
\text { median } \\
\text { range }\end{array}$ & $\begin{array}{c}8.64 \\
6.91 \\
(4.62-33.22)\end{array}$ & & $\begin{array}{c}7.7 \\
7.09 \\
(4.72-12.19)\end{array}$ & \\
\hline $\begin{array}{l}\text { Disease-free } \\
\text { survival "yes" }\end{array}$ & $\begin{array}{l}\text { mean } \\
\text { median } \\
\text { range }\end{array}$ & $\begin{array}{c}9.78 \\
7.04 \\
(4.62-37.7)\end{array}$ & 0.0127 & $\begin{array}{c}10.4 \\
47.67 \\
(4.72-37.7)\end{array}$ & 0.0297 \\
\hline $\begin{array}{l}\text { Disease-free } \\
\text { survival "no" }\end{array}$ & $\begin{array}{l}\text { mean } \\
\text { median } \\
\text { range }\end{array}$ & $\begin{array}{c}17.11 \\
9.19 \\
(6.77-82.07)\end{array}$ & & $\begin{array}{c}18.11 \\
10.13 \\
(7.13-82.07)\end{array}$ & \\
\hline $\begin{array}{l}\text { 2-year survival } \\
\text { "yes" }\end{array}$ & $\begin{array}{l}\text { mean } \\
\text { median } \\
\text { range }\end{array}$ & $\begin{array}{c}10.33 \\
8.25 \\
(4.62-37.7)\end{array}$ & 0.2157 & $\begin{array}{c}10.99 \\
8.93 \\
(4.72-37.7)\end{array}$ & 0.4496 \\
\hline $\begin{array}{l}\text { 2-year survival } \\
\text { "no" }\end{array}$ & $\begin{array}{l}\text { mean } \\
\text { median } \\
\text { range }\end{array}$ & $\begin{array}{c}18.48 \\
8.8 \\
(4.78-82.07)\end{array}$ & & $\begin{array}{c}19.04 \\
10.34 \\
(4.78-82.07)\end{array}$ & \\
\hline
\end{tabular}

nostic importance in ovarian cancer [17]. Sun et al. [18] have shown that the CD30/CD30L signal triggered during interactions of T cells plays a key role in the differentiation of Th17 cells with the mediation of IL-2. It appears from the experiments of Jurisic et al. [19] that exposure of K562 cells (erythroleukemia) to TNF- $\alpha$ elicits apoptosis through the membrane-associated CD30 ligand. Shedding of the ligand by these cells is an early event, preceding cell disintegration and release of lactic dehydrogenase (LDH). Interestingly, expression of CD30 and elevated levels of SCD30L in serum accompany malignancies of the immune system, such as Hodgkin's lymphoma and anaplastic large-cell lymphoma [10, 11]. Today, B cell lymphomas constitute $90 \%$ of all non-Hodgkin lymphomas (NHL). Breen et al. [20] have recently hypothesized that elevated levels of sCD30L in serum reflect conditions in the immune environment which support the growth of NHL from B cells. The same authors reported markedly elevated SCD30L levels in AIDS patients with $\mathrm{NHL}$ in comparison with controls without the tumor. Purdue et al. [7] found elevated SCD30L levels in serum which preceded by $6-10$ years the diagnosis of $\mathrm{NHL}$, concluding their report that protracted stimulation of $\mathrm{B}$ cells is responsible for the formation of this tumor and that SCD3OL is a strong predictor of NHL. Serum concentrations of SCD3OL have been studied in gravida $[9,21]$ and were found to be elevated in comparison with non-gravida. No correlation was noted between gestation time and SCD30L level. Intrauterine growth restric- tion and pre-eclampsia are accompanied by lower serum SCD30L concentrations than in healthy gravida $[9,21]$. Gestational pyelonephritis augments SCD30L concentration in serum regardless of the etiologic factor [21]. Sun et al. [8] demonstrated the implication of the CD30/CD30L signal in colorectal cancer developing from an intestinal polyp and observed significant differences in the levels of CD30L in patients with colorectal cancer or polyps and healthy controls. According to some researchers, diminished concentration of CD30L leads to a disequilibrium between cytokines from Th1 and Th2 cells and may be directly responsible for carcinogenesis in the normal intestinal epithelium of the polyp [8, 22].

Great progress has been made during recent years in the use of antibodies as carriers of cytotoxic drugs (antibody drug conjugates - ADCs) [3]. AGN-35 is a monoclonal antibody which has already been used in CD30-positive NHL $[3,23]$. Trials are ongoing on ADCs in Crohn's disease. A soluble murine antibody against CD30L (CD30-lg) is capable of inhibiting Th17dependent cell differentiation and alleviating symptoms of colitis in mice. Thus, modulation of the CD30/CD30L signal is emerging as a new form of biological therapy in inflammatory conditions of the gastrointestinal system [3].

So far, only one report on SCD30L in patients with ovarian cancer has been published [5]; higher concentrations of SCD30L were found compared with benign cystadenomas and teratomas of the ovary and the ligand was undetectable 
in healthy women. Moreover, the concentration of SCD3OL in the fluid collected from ovarian tumors significantly exceeded that in serum [5]. Mielczarek-Palacz et al. [5] believe that the presence of $\mathrm{SCD} 30 \mathrm{~L}$ in the serum of patients with ovarian cancer may be attributed to shedding of the ligand from the cell membrane and that this process interferes with the binding of CD30L to CD30, thereby inhibiting apoptosis of cancer cells.

Studies on the expression of CD30L by ovarian cancer cells have not been published, so we are unsure whether the source of SCD30L in serum is the cancer cell itself or other processes accompanying carcinogenesis, such as the immune response to the tumor. Cossu-Rocca et al. [24] found that SCD30L was not expressed in $100 \%$ of cases of ovarian dysgerminoma and suggested that the ligand may be useful in the differential diagnosis of ovarian tumors. Hopefully, future studies will be able to improve our understanding of the patterns of SCD30L in ovarian pathologies.

Concentrations of SCD3OL found by us in ovarian cancer patients at diagnosis $(11.81 \mathrm{ng} / \mathrm{ml})$ and at relapse $(21.48 \mathrm{ng} / \mathrm{ml})$ were markedly higher than those reported by Mielczarek-Palacz et al. $(5.09 \mathrm{ng} / \mathrm{ml})$ [5], even though we used the same diagnostic test. In view of the fact that all factors participating in inhibition or activation of apoptosis may in consequence support or suppress tumor growth, we decided to correlate serum levels of SCD30L with some prognostic factors in ovarian cancer. On the whole, poor prognosis in our patients was heralded by augmented levels of sCD30L. Significantly higher concentrations of the ligand were noted in patients resistant to platinum analogs and necessitating neoadjuvant therapy due to progression of the tumor, as well as in patients without complete remission after first-line chemotherapy. The risk of death during the first two years after diagnosis and the risk of relapse were higher in patients with elevated SCD3OL levels. We were unable to find a similar study in the literature for comparative purposes, apart from the work of Kusuda et al. [17], who demonstrated that expression of cytokine mRNA by Th1 and Th2 cells is significantly higher in serous than other tumors without any difference depending on the stage and grade. Higher levels of cytokines were associated with a better prognosis. As expression of CD3OL has been demonstrated in Th1, Th2, and many other cell types, the poor prognosis in our patients with elevated SCD30L levels in serum can be attributed to an active and abnormal immune response.

A limitation of the study is certainly the small number of patients, as well as the short period of observation. Further analysis will be required inter alia after 5 years of observation and analysis of the other groups of patients with ovarian cancer, e.g. disease in remission. On the basis of greater clinical material in the future it will be possible to perform multiple and univariate analysis. The group of patients who received neoadjuvant chemotherapy may seem controversial because neoadjuvant chemotherapy in ovarian cancer patients is not yet a standard procedure. Unpublished own experience and other authors suggest similar long-term results of treatment in patients after primary surgery and after neoadjuvant chemotherapy at the beginning of treatment $[25,26]$.
In conclusion, it appears plausible that the CD30/CD30L complex participates in the process of apoptosis of ovarian cancer cells. The sources of elevated SCD30L concentration in the serum of ovarian cancer patients remain unclear and more research is needed to resolve this issue. Maximally effective therapies in ovarian cancer can only be achieved through detailed understanding of the biology of this neoplasm. Our present study might initially suggest that elevated concentration of SCD3OL can be an important finding prognosticating a poor prognosis and is associated with platinum resistant and refractory cases of ovarian cancer. However, studies are needed on larger groups of patients.

The authors declare no conflict of interest.

\section{References}

1. Van Cruchten S, Van Den Broeck W. Morphological and biochemical aspects of apoptosis, oncosis and necrosis. Anat Histol Embryol 2002; 31: 214-23.

2. Han SI, Kim YS, Kim TH. Role of apoptotic and necrotic cell death under physiologic conditions. BMB Rep 2008; 41: 1-10.

3. Senter PD. Potent antibody drug conjugates for cancer therapy. Curr Opin Chem Biol 2009; 13: 235-44.

4. Knowles DM. Immunophenotypic markers useful in the diagnosis and hematopoietic neoplasm. In: Knowles DM (ed.). Neoplastic Hematopathology. Lippincott Williams \& Wilkins, Philadelphia, PA 2001; 93-226.

5. Mielczarek-Palacz A, Kondera-Anasz Z, Sikora J, Sodowski K, Switała J, Kubina R. Concentration of soluble ligand for receptor CD30 (sCD30L) - marker of apoptosis in women with ovarian tumor. Ginekol Pol 2009; 80: 494-7.

6. Diehl V, Bohlen H, Wolf J. CD30: cytokine receptor, differentiation marker or target molecule for specific immune response? Ann Oncol 1994; 5: 300-2.

7. Purdue MP, Lan Q, Martinez-Maza O, et al. A prospective study of serum soluble CD30 concentration and risk of non-Hodgkin lymphoma. Blood 2009; 114: 2730-2.

8. Sun X, Yamada H, Shibata K, Muta H, Tani K, Podack ER, Iwakura Y, Yoshikai Y. CD30 ligand is a target for a novel biological therapy against colitis associated with Th17 responses. J Immunol 2010; 185: 7671-80.

9. Laskowska M, Laskowska K, Oleszczuk J. Soluble CD30 in normotensive pregnant women with isolated fetal intrauterine growth restriction: a comparison with preeclamptic women. J Reprod Immunol 2010; 86: 122-5.

10. Kennedy MK, Willis CR, Armitage RJ. Deciphering CD30 ligand biology and its role in humoral immunity. Immunology 2006; 118: 143-52.

11. Horie R, Watanabe T. CD30: expression and function in health and disease. Semin Immunol 1998; 10: 457-470.

12. Shimozato O, Takeda K, Yagita H, Okumura K. Expression of CD30 ligand (CD153) on murine activated T cells. Biochem Biophys Res Commun 1999; 256: 519-526.

13. Oflazoglu E, Grewal IS, Gerber H. Targeting CD30/CD3L in oncology and autoimmune and inflammatory diseases. Adv Exp Med Biol 2009; 647: 174-85.

14. Lane PJ, Gaspal FM, Kim MY. Two sides of cellular coin: CD4(+)CD3cells regulate memory responses and lymph node organization. Nat Rev Immunol 2005; 5: 655-60.

15. Bowen MA, Lee RK, Miragliotta G, Nam SY, Podack ER. Structure and expression of murine CD30 and its role in cytokine production. J Immunol 1996; 156: 442-9.

16. Lee SY, Lee SY, Kandala G, Liou ML, Liou HC, Choi Y. CD30/TNF receptor-associated factor interaction: NF-kappa B activation and binding specificity. Proc Natl Acad Sci U S A 1996; 93: 9699-703.

17. Kusuda T, Shigemasa K, Arihiro K, Fujii T, Nagai N, Ohama K. Relative expression levels of Th1 and Th2 cytokine mRNA are independent 
prognostic factors in patients with ovarian cancer. Oncol Rep 2005; 13: 1153-8.

18. Sun X, Yamada H, Shibata K, Muta H, Tani K, Podack ER, Yoshikai Y. CD30 ligand/CD30 plays a critical role in Th17 differentiation in mice. J Immunol 2010; 185: 2222-30.

19. Jurisic V, Srdic-Rajic T, Konjevic G, Bogdanovic G, Colic M. TNF- $\alpha$ induced apoptosis is accompanied with rapid CD30 and slower D45 shedding from K-562 cells. J Membr Biol 2011; 239: 115-22.

20. Breen EC, Fatahi S, Epeldegui M, Boscardin WJ, Detels R, MartínezMaza O. Elevated serum soluble CD30 precedes the development of AIDS-associated non-Hodgkin's B cell lymphoma. Tumor Biol 2006; 27: 187-94.

21. Kusanovic JP, Romero R, Esoinoza J, et al. Maternal serum soluble CD30 is increased in pregnancies complicated with acute pyelonephritis. J Matern Fetal Neonatal Med 2007; 20: 803-11.

22. Contasta I, Berghella AM, Pellegrini P, Adorno D. Passage from normal mucosa to adenoma and colon cancer: alternation of normal sCD30 mechanism regulating TH1/TH2 cell functions. Cancer Biother Radiopharm 2003; 18: 549-57.

23. Kim KM, McDonagh CF, Westendorf L, et al. Anti-CD30 diabody drug conjugates with potent antitumor activity. Mol Cancer Ther 2008; 7: 2486-97.

24. Cossu-Rocca P, Jones TD, Roth LM, Eble JN, Zheng W, Karim FW, Cheng L. Cytokeratin and CD 30 expression in dysgerminoma. Hum Pathol 2006; 37: 1015-21.

25. McLean KA, Shah CA, Thompson SA, Gray HJ, Swensen RE, Goff BA. Ovarian cancer in the elderly: outcomes with neoadjuwant chemotherapy or primary cytoreduction. Gynecol Oncol 2010; 118: 43-6.

26. Rauh-Hain JA, Rodriguez N, Growdon WB, Goodman AK, Boruta DM 2nd, Horowitz NS, del Carmen MG, Schorge JO. Primary debulking surgery versus neoadjuvant chemotherapy in stage IV ovarian cancer. Ann Surg Oncol 2012; 19: 959-65.

\section{Address for correspondence}

Anita Chudecka-Głaz

Al. Powstańców Wielkopolskich 72

70-111 Szczecin, Poland

tel./fax: +48 9146613 32/+489146613 34

e-mail: anitagl@poczta.onet.pl

Submitted: $\quad 8.02 .2012$

Accepted: $\quad 21.06 .2012$ 